\title{
Contents Vol. 37, 1991
}

$\begin{array}{ll}\text { A. Author Index } & 383 \\ \text { Subject Index } & 384\end{array}$

\section{Founded 1968 and continued 1968-1986 by W. Riss, New York, N.Y. Official Organ of the J.B. Johnston Club}

\author{
Editor-in-Chief \\ R. Glenn Northcutt, La Jolla, Calif. \\ Assistant Managing Editor \\ Mary Sue Northcutt, La Jolla, Calif. \\ Editorial Board \\ E. Armstrong, Washington, D.C. D.A. Bodznick, Middletown, Conn. R.L. Boord, Newark, Del. Si. \\ Brauth, College Park, Md. C.B.G. Campbell, Washington, D.C. J.T. Corwin, Charlottesville, Va. L.S. \\ Demski, Lexington, Ky. T,E. Finger, Denver, Colo. B. Fritzsch, Omaha, Nebr. W. Hodos, College Park, \\ Md. H. Ito, Tokyo \\ J.I. Johnson, East Lansing, Mich. HJ. Karten, La JoUa, Calif.
}

A.H.M. Lohman, Amsterdam C.A. McCormick, Oberlin, Ohio G.F. Martin, Columbus, Ohio J.C. Montgomery, Auckland A. Parent, Quebec J.D. Pettigrew, St. Lucia M.H. Rowe, Athens, Ohio H. Scheich, Darmstadt W.J.A.J. Smeets, Amsterdam N.P. Vesselkin, Leningrad W.I. Welker, Madison, Wise. W. Wilczynski, Austin, Tex. 


\section{KARGER \\ Contents Vol. 37,1991}

No.1

No. 3

Dendritic Morphology of Visual Callosal Neurons in theGolden HamsterDiao, Y.-C; So, K.F

Morphology, Distribution and Innervation of the Lateral-LineReceptors of the Florida Gar, Lepisosteus platyrhincusSong, J.; Northcutt, R.G ….......................................................................... 10

The Primary Projections of the Lateral-Line Nerves of the Florida Gar, Lepisosteus platyrhincusSong, J.; Northcutt, R.G 38

Announcements

64

\section{$W m$}

The Eye of a Procellariiform Seabird, the Manx Shearwater,Puffinus puffinus: Visual Fields and Optical StructureMartin, G.R.; Brooke, M. de L. 65

Novel Area Serving Binocular Vision in the Retinae of Procellariiform SeabirdsHayes, B.; Martin, G.R.; Brooke, M. de L

Encephalization in Hummingbirds (Trochilidae)

Rehkamper, G.; Schuchmann, K.-L.; Schleicher, A.; Zilles, K. 85

Behavioral and Physiological Consequences of Unilateral Ablation of the Nucleus Isthmi in the Leopard Frog Gruberg, E.R.; Wallace, M.T.; Caine, H.S.; Mote, M.I. . 92

Autoradiographic Study of the Retinal Projections in the Chinese Pangolin, Manis pentadactylaLee, G.Y.-P.; Chen, S.-T.; Shen, C.-L. 104

Distribution of the Vestibular Neurons Projecting to the Oculomotor and Trochlear Nuclei in RabbitsLabandeira-Garcia, J.L.; GuerraSeijas, M.J.; Labandeira-Garcia, J.A.; Jorge-Barreiro, F.J ....... Ill

Announcements .... 124

Quantitative Development of Brain and Brain Structures in

Birds (Gall i formes and Passeri formes) Compared to that in

Mammals (Insectivores and Primates)

Rehkamper, G.; Frahm, H.D.; Zilles, K.

Electrocorticograms of Hippocampal and Dorsal Cortex of

Two Reptiles: Comparison with Possible Mammalian Ho-

mologs

Gaztelu, J.M.; Garcfa-Austt, E.; Bullock, T.H.

Neuronal Motion After-Response Induced in the Tectal Neurons of Toads by Moving Textured Background

Tsai, H.-J 161 
Distribution of Camosine-Like Immunoreactivity in the Brain of the Crested Newt

Artero, C; Mulatero, B.; BifTo, S.; Andreone, C; Gozzo, S.;

Margolis, F.L.; Fasolo, A .......................................................... 168

Comparative Aspects of the Distribution of Substance P and

Dopamine Immunoreactivity in the Substantia Nigra of

Amniotes

Smeets, WJ.A.J

No. 4

Number and Distribution of Retinal Ganglion Cells in AnubisBaboons (Papio anubis)Fischer Q.S.; Kirby, M.A,

Inter- and I ntrasexuai Dimorphisms in the Vocal Control System of a Teleost Fish: Motor Axon Number and SizeBass, A.; Andersen, K. 204

A Brain Atlas of the Northern Fulmar (Fulmarus glacialis) inStereotaxic CoordinatesMatochik, J.A.; Reems, C.N.; Wenzel, B.M 215

rV

Contents

No. 5

No. 6

Preface

Eaton, R.C. .250

Ludwig Mauthner (1840-1894): Neuroanatomist and Noted

Ophthalmologist in Fin-de-Siecle Vienna

Seyfarth, E.-A.; Zottoli, S.J.

Vibration-Evoked Startle Behavior in Larval Lampreys

Currie, S.N

Role of the Mauthner Cell in Sensorimotor Integration by the

Brain Stem Escape Network

Eaton, R.C; DiDomenico, R.; Nissanov, J.

Role of Medullary Networks and Postsynaptic Membrane

Properties in Regulating Mauthner Cell Responsiveness to Sensory Excitation

Faber, D.S.; Korn, H.; Lin, J.-W..

Spinal Network of the Mauthner Cell 


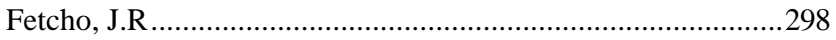

Amphibian Mauthner Cells

Will, U..............................................................................317

Retinofugal and Retinopetal Projections in the Green Sunfish,

Lepomis cyanellus

Northcutt, R.G.; Butler, A.B..................................................... 333

Laminar Distribution of Cytochrome Oxidase Staining in Cetacean I socortex

Revishchin, A.V.; Garey, L.J.....

355

Motor Neurons and Motor Columns of the Anterior Spinal

Cord of Salamanders: Post hatching Development and Phy-

logenetic Distribution

Nishikawa, K.C.; Roth, G.; Dicke, U 